\title{
The New Drugs Methodology of Study in Brazil
}

\author{
Cláudia Cândida Silva* \\ Escola Superior de Tecnologia, Universidade do Estado do Amazonas, Brazil
}

Submission: December 19, 2017; Published: January 05, 2017

*Corresponding author: Cláudia Cândida Silva, Escola Superior de Tecnologia, Universidade do Estado do Amazonas, Avenida Darcy Vargas 1200 , Manaus, Amazonas, Brazil, Email: ccsilva@uea.edu.br

Keywords : Drugs; Crystallography; Quantum chemistry; Chemometrics

\section{Opinion}

The drug, according to official definition given by Ministerial Order No. 3.916 / MS / GM, of October 30, 1998, is the chemical that is the active principle of the drug. The word itself derives from the Greek "pharmak", which means, according to Kawano (2006), "that which has the power to translate the impurities". Among the Greeks, victims of the sacrifices offered to the gods were called pharmako, and the food used during communion ceremonies, phármakon. This last word came to integrate the Greek medical terminology and has come to this day with the name of drug. For the Greeks, pharmakon was that which could bring both good and evil, sustain life, or cause death. Medication is a pharmaceutical product, technically obtained or prepared, for prophylactic, curative, palliative or diagnostic purposes [1]. Thus it is possible to say that drug is the drug benefited, industrially or in manufacturing, in dose or therapeutic concentration. The same holds true for semi-solid or liquid formulations. That cream that has an active principle for the purpose of preventing, curing, treating or serving as a diagnosis for pathologies is also considered a medicine.

From discovery to development and the end result of a drug, it lasts around 14 years. It requires great care and continuous research commitment during these years. The process for a new drug goes through three phases: discovery, development and registration in the regulatory body. Biological activity is an expression that describes the beneficial or adverse effects of a drug on living things. When the drug in question is a complex chemical mixture, this activity is produced by the active ingredient of the substance, but can be modified by the other constituents. The main type of biological activity is the toxicity of a substance. The activity is generally dose-dependent and it is not uncommon to have effects ranging from beneficial to adverse as the dosage is increased. The activity depends critically on compliance with the criteria of absorption, distribution, metabolism, and excretion [2].
The physico-chemical properties of certain functional clusters are fundamental in the pharmacodynamic phase of the action of the drugs, stage molecular recognition, since the affinity of a drug for its receptor depends on the sum of the interaction forces of the clusters with complementary sites of the receptor site. The pharmacokinetic phase, absorption, distribution, metabolization and excretion, has direct results on the bioavailability and in the half-life of the drug in the biophase, can also be affected drastically by the variation of the physical and chemical properties of a drug [3]. The most conventional approach to the study of biological activities involves isolation or synthesis of the substance, determination of its three-dimensional structure and in vitro and in vivo tests of the substance. In an attempt to understand its activity, we also have studies of mechanisms of action and possible toxicity. Bioactive molecules can be identified from real (eg. biological, biochemical) or virtual (eg. computational) screenings of natural products, synthetic compounds or combinatorial collections, or by rational planning. It should be noted, however, that in all cases the biological properties must be experimentally determined, and the development of standardized and validated high-quality assays is necessary [4].

From the crystallographic point of view, the most interesting property of the X-rays lies in the fact that, because they have an undulatory character, they suffer the phenomenon of diffraction when they cross networks or reticles whose distance between planes of the same order of incident wave compliance. The crosslinks that fall within the above-mentioned condition are the crystal lattices [5]. Thus, X-ray diffraction by crystals is a phenomenon of fundamental importance for several fields of research because it can be used to obtain information about the relative positions of atoms in a solid. The results from the technique in question provide valuable data for understanding the molecular structure and how this may be related to the particular physical and chemical properties of the test 
substance. Some of the drugs have an asymmetric carbon in their structure. The suppression of chirality in these drugs leads to the disappearance of biological activity. On the other hand, the inversion of the orientation of the clusters in the asymmetric center can lead to a significant modification of the biological activity.

This is an example of a study where crystallographic data are extremely relevant [6]. Nowadays, the number of works is increasing, in which the relationships between chemical structure and biological activity are expressed through mathematical equations. Mathematical equations include parameters representing the physicochemical properties of a drug and its correlation with biological activity [3]. A very large number of different parameters have been introduced over the past 30 years and the number continues to grow, as some scientists believe that with this increase all structure-activity relationship problems would be solved. Chemical-quantum methods, especially semi-empirical methods, are of great importance since they can calculate the properties that directly influence the biological activity in question. This methodology, in general, is based on theoretical data, generated by specific computational programs.

In general, the different biotech strategies discussed produce large amounts of data that must be analyzed quickly and efficiently. In this context, bioinformatics methods play a fundamental role, making possible the organization, management, visualization and interpretation of the generated information. The aim is to establish correlation patterns between the various biochemical and cellular events involved in the disease state (or during treatment with a drug candidate) [7]. One of the major challenges of medicinal chemistry in the drug planning process is to contribute to the increased success rate in the discovery of new chemical entities (NCE).

The integration of experimental and computational methods has enormous importance in the identification and development of new bioactive molecules from collections of real or virtual compounds. Molecular plating is one of the main strategies employed, which consists in predicting the bioactive conformation of a small molecule at the binding site of a macromolecule (target protein), followed by evaluation and classification of the proposed binding mode. A recently used approach is the use of experimental data collected by X-ray diffraction by monocrystals as the basis for the structural studies made with semi-empirical methods [8]. In this way the structures generated in the semiempirical simulations have a real basis. After several simulated molecules with starting point in the experimental base, and with their physicochemical properties duly calculated, one can apply the chemiometric methods suitable for the generation of models where the prediction of increase or decrease of certain properties suggest a drug more efficient [9]. This kind of work saves several hours of experiments, spent on reagents and chemical analysis equipment, and avoids in-vitro and in vivo tests based on random attempts, from more robust data than just quantum method simulations.

\section{References}

1. Brasil Lei n. 5991, De 17 de dezembro de (1973) Dispõe sobre o controle sanitário do comércio de drogas, medicamentos, insumos farmacêuticos e correlatos, e dá outras providências. Diário oficial da República Federativa do Brasil, Brasília.

2. Katzung B, Masters S, Trevor A (2014) Basic and Clinical Pharmacology (12 ${ }^{\text {th }}$ Edition) ISBN 978-0071764018.

3. Andricopulo AD, Salum LB, Abraham DJ (2009) Structure-based drug design strategies in medicinal chemistry. Curr Top Med Chem 9(9): 771-790.

4. Bhogal N, Balls M (2008) Translation of new technologies: from basic research to drug discovery and development. Curr Drug Discov Technol 5(3): 250-262.

5. Cullity BD, Stock SR (2001) Elements of X-ray Diffraction (3 $3^{\text {rd }}$ Edition) Prentice-Hall, New York.

6. Coelho FAS, Fármacos e quiralidade (2001) Cadernos Temáticos de Química Nova na Escola 3.

7. Farutin V, Lori Masterson, Adriano D Andricopulo, Jianming Cheng, Brad Riley, et al. (1999) Structure-activity relationships for a class of inhibitors of purine nucleoside phosphorylase. J Med Chem 42(13): $2422-2431$

8. Kawano DF, Pereira LRL, Ueta JM, Freitas O (2006) Acidentes com os medicamentos: como minimizá-los? Rev Bras Cienc Farm 42(4): 487495.

9. Silva CC (2005) Correlação estrutura-atividade de algumas fenazinas. Tese de doutorado. IQSC USP São Paulo, Brazil. 
- Quality Editorial service

- Swift Peer Review

- Reprints availability

- E-prints Service

- Manuscript Podcast for convenient understanding

- Global attainment for your research

- Manuscript accessibility in different formats ( Pdf, E-pub, Full Text, Audio)

- Unceasing customer service

Track the below URL for one-step submission https://juniperpublishers.com/online-submission.php 